\title{
音響励起と二次フィルム流を用いた噴流拡散制御に関する研究 薄い環状流の局所的変動について \\ Diffusion control of jet by Acoustically driven Secondary Film Flow
}

\author{
○正 宮城 徳誠（日大短大）＼cjkstart正 木村 元昭（日大）
}

Norimasa Miyagi, Department of Engineering Science, Junior College, Nihon University Motoaki Kimura, Department of Mechanical Engineering, College of Science \& Technology, Nihon University

The velocity field of the controlled jet is measured x-type hot wire probe. From the result of power spectrum analysis of streamwise velocity fluctuation at the nozzle exit, in the case of $\mathrm{VR}=1.0$, a resonant mode is found for the frequency of acoustic excitation, and this resonant mode contributes to the promotion jet diffusion. In the case of $\mathrm{VR}=0.5$, a lot of mode are found and non-liner interference between different modes. This non-linear interaction between different modes seems to suppress the radial direction velocity fluctuation of the film flow, and seems to restrain the diffusion of the jet. Key Words : Jet, Flow Control, Acoustic Control, Secondary Film Flow, Mixing

\section{1. 緒言}

著者らは, 今まで噴流の初期領域におけるエントレイメン トの制御を念頭に, 速度均一型ノズルから噴出される自由噴 流の外側に，薄い環状流れ（二次フィルム流）をつくり，さ らにスピーカによる音響励起を与え, 噴流混合の抑制・拡散, 双方を目的とした噴流制御を行っている 1)2). 主流とフィル 厶流との流速比 VR=0.5 の場合, 音響励起を与えても噴流の 拡散は抑制され，VR=1.0 でさらに主流に対して $\mathrm{St}=0.3$ と なるように音響励起を与えると最も噴流が拡散すると示し ている. 本報告では, 音響励起された薄い環状流の速度変動 が主流噴流にどのように影響を与えるかに着目し，熱線流速 計によって得られた速度分布にスペクトル解析を行った。

2. 実験装置および方法

Fig.1 に本研究で使用するノズルの概略図を示す(1). ノズ ルは, 主流ノズル内径 $\mathrm{d}=8 \mathrm{~mm}$, リム厚さ $0.5 \mathrm{~mm}$ (主流ノズ ル外径 $9 \mathrm{~mm}$ )の軸対称均一速度ノズルである. その外側に内 径 $12 \mathrm{~mm}$ の二次ノズルを同軸に設定し, 2 次フィルム流を形 成した $(2$ 次フィルム流の厚さは $1.5 \mathrm{~mm})$. Fig.2 に実験装置 の概要図(1)を示す．エアーコンプレッサーによって，主流側 とフィルム流側へそれぞれの流体が供給され，それぞれフロ ーコントローラによって流量が設定される. 主流の噴出速度 $\mathrm{V}_{0}$ は, 主流ノズル内径 $\mathrm{d}=2 \mathrm{r}$ を代表長さとし, レイノルズ数 $\mathrm{Re}=3,000$ に合うように設定した. フィルム流速 $\mathrm{V}_{\mathrm{f}}$ は主流噴 出速度 $\mathrm{V}_{0}$ を基準に速度比 $\mathrm{VR}\left(=\mathrm{V}_{\mathrm{f}} / \mathrm{V}_{0}\right)=0.5$ および 1.0 に合わ せて流速を調整した. フィルム流はその後, スピーカの正弦 波を加え脈動させ,フィルム流としてノズルから噴出させた フィルム流に加える音波の圧力は, 空気がノズルに入る直前 の圧力変動を計測し，その変動の実効值 Ps が $5 \mathrm{~Pa}$ となるよ うにアンプで設定した. 圧力波形はオシロスコープにも投影 し，共鳴などの影響がないことを確認している．音波の周波 数 $\mathrm{f}$ は主流ノズル内径 $\mathrm{d}$ を用いて，ストローハル数 $\mathrm{St}_{0}=0.3$ となるように $\mathrm{f}_{\mathrm{a}}=220 \mathrm{~Hz}$ と設定した．測定した座標系は，ノ ズル出口中央を原点として, 噴出方向を $\mathrm{x}$, ノズル半径方向 をyとした。

速度変動の測定は， $\mathrm{x}$ 型熱線流速計を用いて測定した．小 型 $\mathrm{x}$ 型熱線プローブ(TSI 1248A-10)を流れ方向に平行にな るように設置し, 2 チャンネル分の CTA ユニットを介して, 流れ方向 $(\mathrm{x}$ 方向成分 $\mathrm{U}$ ) と半径方向 $(\mathrm{y}$ 方向成分 $\mathrm{v}$ ) とに分けて 測定する. $\mathrm{AD}$ ボードにて 2 成分速度変動とスピーカとの同 期信号を同時に取り込み，PC 上にて速度への変換と時間平 均処理・位相平均処理を行った。熱線ブローブの測定点はプ ローブとノズルとの干渉を避けるために, プローブ先端が出 ロから $1 \mathrm{~mm}$ 離れた断面で, 主流ノズル中心を原点として,

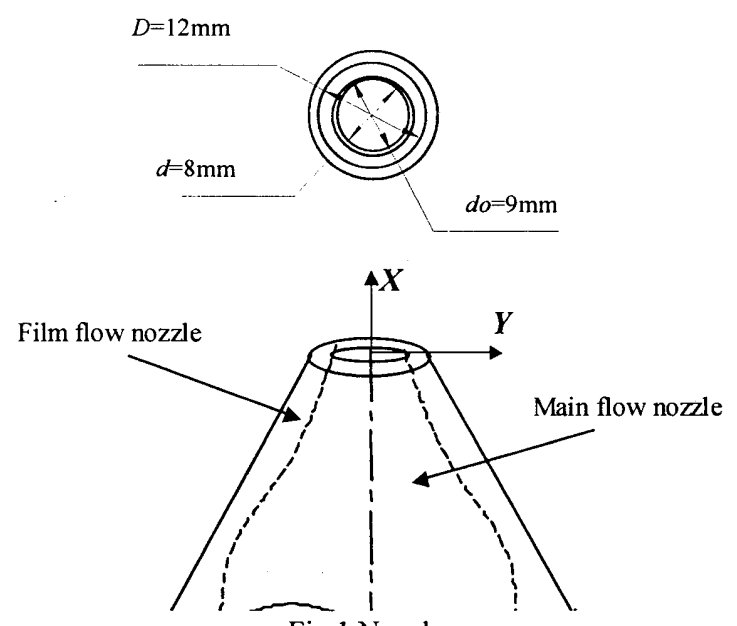

Fig 1 Nozzle

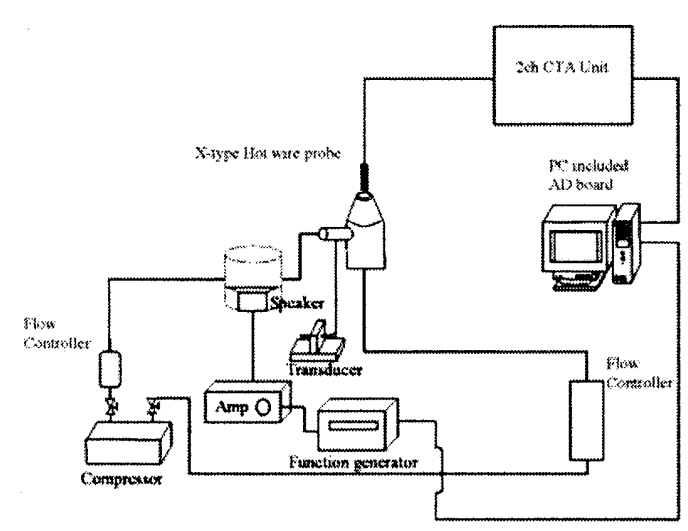

Fig 2 Experimental apparatus

流れ方向に $\mathrm{x}=0 \sim 40 \mathrm{~mm}(\mathrm{x} / \mathrm{d}=0 \sim 5)$ を $1 \mathrm{~mm}$ 間隔で, 半径方 向に $\mathrm{y}=-8 \sim 12(\mathrm{y} / \mathrm{r}=-2 \sim 3) \mathrm{mm}$ を $0.5 \mathrm{~mm}$ 間隔とした。

スペクトル解析はスピーカの同期信号をもとに速度デー 夕を位相平均化し， PC 上で 4096 サンプル(212 サンプル)の データに対してDFFT 演算を行った。

3.実験結果

Fig.3 は, VR=0.5 および VR=1.0の場合の流れ方向速度分 布 $\mathrm{U} / \mathrm{V}_{0}$. 流れ方向 $\mathrm{x} / \mathrm{d}$ ごとに縦方向の座標を移動しており, 各分布線図の両端の值が $U / \mathrm{V}_{0}=0$ を示寸. 同図(a)の $\mathrm{U} / \mathrm{V}_{0}$ においてどの測定点においても中心軸付近での流速は 
$\mathrm{U} / \mathrm{V}_{0}=1.0$ となり; ハット型の速度分布を形成する. $\mathrm{x} / \mathrm{d}=0$ において, 主流とフィルム流との間のギャップの影響が現れ るが( $\mathrm{y} / \mathrm{r}=1.0 \sim 1.125), \mathrm{x} / \mathrm{d}=2$ 以降はその影響は解消され，そ の外側にゆるやかな剪断層を形成している. 出口付近 $\mathrm{x} / \mathrm{d}=0$ での乱流強度 $\mathrm{u}_{\mathrm{rms}}^{\prime} / \mathrm{N}_{0}$ は, 音響励起による薄い環状流への変 動がフィルム流中 $(\mathrm{y} / \mathrm{r}=1.25)$ で $9.7 \%$, 主流中心付近では 11.8\%の変動となった。これにより薄い環状流の変動が主流 全体一影響を与えていることが分かる. 同図(b)VR=1.0の場 合, 主流と 2 次フィルム流とのギャップの影響が大きく, こ の $0.5 \mathrm{~mm}$ の間における速度は主流, フィルム流の $25 \%$ 程度 の速度となった.このギャップの影響も $\mathrm{x} / \mathrm{d}=2$ 以降は主流と フィルム流との付着により解消され, その後, 主流中心から 丸みを帯びた速度分布となった. 音響励起によるフィルム流 の速度変動は出口付近で $20 \%$, フィルム流付着後の中心付近 までの乱れ強度は $10 \%$ 程度となった。

次にスペクトル解析を行った結果を示す.フィルム流の内 側と外側の影響を確認するため, 其々の周波数 $\mathrm{f}$ を $\mathrm{St}=\mathrm{fD} / \mathrm{U}$ を用いて無時限化するために, 流速Uを速度が遅くなるフィ ルム流側のみ各測定点における時間平均速度 U(y)を用い, 代表直径 D は, 主流側は主流ノズル内径 $\mathrm{D}=8 \mathrm{~mm}$, フィルム 流内縁 $\mathrm{y} / \mathrm{r}=1.125$ で主流ノズル外形 $\mathrm{D}=9 \mathrm{~mm}$, フィルム流中 と外縁ではフィルム流ノズル内径 $\mathrm{D}=12 \mathrm{~mm}$ を適用した。 こ れにより速度の遅くなるフィルム流側は無時限周波数が大 きくなり，図中では右にずれることになる. Fig. 4 にR=0.5 の場合の周波数 $\mathrm{f}$ を無時限周波数 St としたスペクトル強度 分布を示す.これらの図も縦軸を移動させながら示している. $\mathrm{y} / \mathrm{r}=0 \sim 1.0$ が主流に対応し, $\mathrm{y} / \mathrm{r}=1.125 \sim 1.5$ がフィルム流に 対応している. 同図より, 音響励起周波数 $\mathrm{f}_{\mathrm{a}}=220 \mathrm{~Hz}$ だけで はなく様々な周波数でスペクトル強度が高くなっているこ とが分かる. とくに音響励起周波数の半分の周波数 $\mathrm{f}_{\mathrm{n}}=110 \mathrm{~Hz}$ が立ち上がっており， $110 \mathrm{~Hz}$ ごとにスペクトル強 度が高くなった．主流側の $\mathrm{f}_{\mathrm{a}}=220 \mathrm{~Hz}$ に相当するストロー八 ル数は $\mathrm{St}=0.34$ であり, これはフィルム流側の周波数 $\mathrm{f}=110 \mathrm{~Hz}$ に相当する. また, フィルム流内縁の $\mathrm{f}_{\mathrm{a}}=220 \mathrm{~Hz}$ に 相当するストローハル数は $\mathrm{St}=0.58$ であり, これは主流側で $\mathrm{f}=380 \mathrm{~Hz}$ ，フィルム流側で $\mathrm{f}=165 \mathrm{~Hz}$ に相当し，その周波数 でのスペクトル強度も高くなっている.これにより, 音響励 起による速度変動は, フィルム流内縁における変動により主 流側に影響を与え, 影響を与えられた主流側はフィルム流側 に 2 倍の周期となる影響を与えるように変動を与えている と考えられる. VR=0.5の場合は,これらの変動の伝播より， 様々な周波数のスペクトル強度があらわれ非線形干涉を起 こしている.

Fig.5 は VR=1.0 の場合のスペクトル強度分布図である. 元のスペクトル強度では $\mathrm{fa}=220 \mathrm{~Hz}$ に対する $\mathrm{f}=110 \mathrm{~Hz}$ の高 い強度はあらわれないが，周期が半分となる $\mathrm{f}=440 \mathrm{~Hz}$ での 高い強度があらわれ, $\mathrm{f}=220 \mathrm{~Hz}$ ごとに高い強度分布となった． 同図, フィルム流内縁 $\mathrm{y} / \mathrm{r}=1.125$ の $\mathrm{f}_{\mathrm{a}}=220 \mathrm{~Hz}$ に対応するス トローハル数は $\mathrm{St}=0.65$ となり主流側の周波数 $\mathrm{f}=440 \mathrm{~Hz}$ に 相当する. また，フィルム流が主流に付着する $\mathrm{x} / \mathrm{d}=1$ におい て主流側の $\mathrm{f}=220 \mathrm{~Hz}$ に相当するストローハル数は $\mathrm{St}=0.34$ となりフィルム流側の周波数 $\mathrm{f}=110 \mathrm{~Hz}$ 相当する. また, $\mathrm{x} / \mathrm{d}=1$ 以降では $\mathrm{VR}=0.5$ の場合と同様に $\mathrm{f}=110 \mathrm{~Hz}$ の高いスペクト ル強度があらわれ, フィルム流の変動によって主流は励起さ れ, その変動がフィルム流の 2 倍の周期となるように変動を 与えていることが分かった。

最後にこれらの変動の影響を記述する. VR=0.5 の場合, ノズル付近での多数の周波数による非線形干渉は, 主流中心 軸上 $(\mathrm{y} / \mathrm{r}=0)$ でも，フィルム流中 $(\mathrm{y} / \mathrm{r}=1.25)$ でも $\mathrm{x} / \mathrm{d}=5$ まであ らわれた. しかし, $\mathrm{y} / \mathrm{r}=1.25$ での変動は, 主流に比べて流速 が遅く, $\mathrm{y} / \mathrm{r}=0$ での無時限周波数が $\mathrm{St}=0.34$ から大きくはな れており，互いに干渉が効きにくくなった。これによりフィ
ルム流の外側に大規模渦を励起できず，噴流の拡散が抑制さ れたと考えられる. また, VR=1.0の場合, 主流中心とフィ ルム流ともに無時限周波数 $\mathrm{St}=0.34$ の変動が維持されてお り，積極的にフィルム流の外側にも大規模渦を励起し，噴流 が拡散したと考えられる。このようにフィルム流と音響励起 によって, 主流とフィルム流が相互に局所的な干涉しあうこ とにより，噴流拡散の抑制・促進両面の制御が可能である.

4. まとめ

音響励起を与えたフィルム流は, まず主流に音響励起周波 数と同じ変動を与える. 主流とフィルム流との流速比により, 局所的な無時限周波数が変わり, 相互の干涉が抑制にも促進 にも影響を与えている.

\section{参考文献}

（1）宮城，木村 他 機論 B 71 巻 712 号, (2005)

(2) Miyagi, Kimura, et.al 13th International Heat Transfer Conference, CD·ROM, 2006

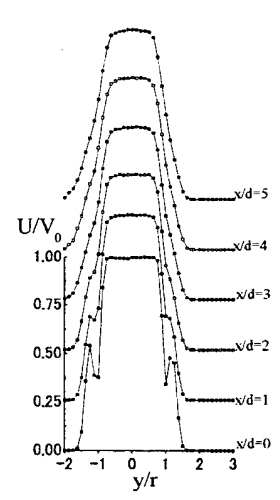

(a)

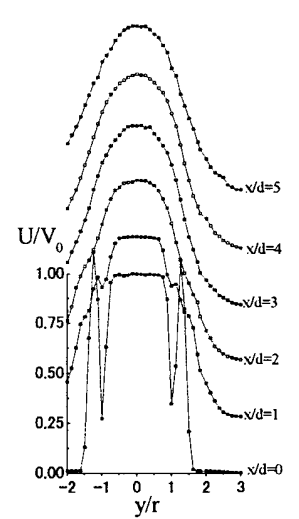

(b)
Fig.3 Velocity profiles (a) as VR=0.5, (b) as $V R=1.0$

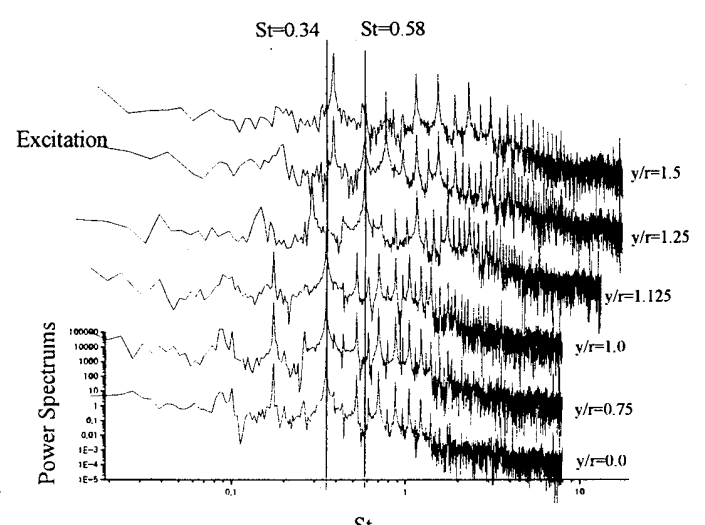

St

Fig.4 Power Spectrum at VR=0.5

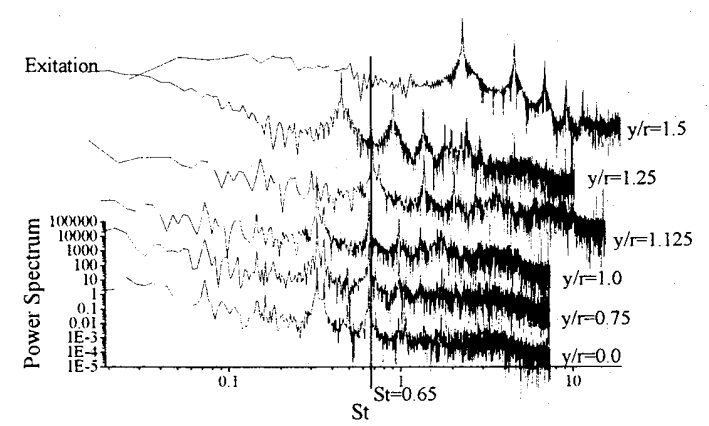

Fig. 5 Power Spectrum as VR=1.0 